\title{
Moyamoya Disease in a Child with Germ Cell Tumor
}

\section{Germ Hücreli Tümörü Olan Bir Çocukta Moyamoya Hastalığı}

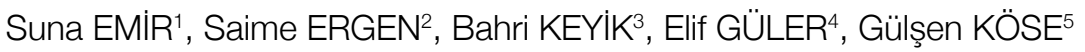

\author{
${ }^{1}$ Ankara Children's Hematology Oncology Training and Research Hospital, Department of Pediatric Hematology Oncology, Ankara, \\ Turkey \\ 2Dumlupınar University, Faculty of Medicine, Deparment of Pediatrics, Kütahya, Turkey \\ ${ }^{3}$ Yıldırım Beyazıt Training and Research Hospital, Department of Radiology, Ankara, Turkey \\ ${ }^{4}$ Gaziantep University, Faculty of Medicine, Deparment of Pediatric Hematology Oncology, Gaziantep, Turkey \\ ${ }^{5}$ Şişli Etfal Training and Research Hospital, Department of Pediatric Neurology, İstanbul, Turkey
}

\begin{abstract}
Moyamoya disease (MMD) is a cerebrovascular condition that predisposes affected patients to stroke in association with progressive stenosis of the intracranial internal carotid arteries and their proximal branches. Moyamoya disease has been described in association with a variety of congenital and acquired diseases. Some congenital hematological diseases (Fanconi anemia, sickle cell anemia), genetic syndromes (Apert's syndrome, Seckel syndrome, Robinow syndrome, Down syndrome, neurofibromatosis type I), metabolic diseases (homocystinuria) are known to associated with Moyamoya syndrome. It is also known that MMD may develop after cranial radiotherapy in children with sella/ chiasma region tumors or after prophylactic cranial irradiation for leukemia. However, there is no data regarding the presence of an association between ovarian tumor and MMD. Here, we report a case of an 8-year-old girl with recurrent ovarian tumor developed MMD after salvage chemotherapy.
\end{abstract}

Key Words: Cancer, Germ cell tumor, Moyamoya disease, Ovarian tumor, Vasculopathy

\section{ÖZET}

Moyamoya hastalığı (MMH) internal karotid arterler ve proksimal dallarının ilerleyici stenozuyla birlikte hastalarda felçlere zemin hazırlayan serebrovasküler bir durumdur. Moyamoya hastalığı çeșitli doğumsal ve edinsel bozukluklar ile ilişkili olarak tarif edilmiştir. Konjenital hematolojik bozukluklar (Fanconi anemisi, orak hücreli anemi), genetik sendromlar (apert sendromu, Seckel sendromu, Robinow sendromu, Down sendromu, nörofibromatosiz tip 1), homosistinüri gibi metabolik bozukluklar Moyamoya hastalığı ile ilişkili olarak bilinmektedir. Aynı zamanda sella/kiazma bölgesi tümörlerinde ve lösemi nedeniyle profilaktik radyoterapi alan hastalarda MMH geliştiği bilinmektedir. Şimdiye dek MMH ile over tümörü arasında bir ilişki tanımlanmamıştır. Burada, tekrarlayan over tümörü olan, kurtarma kemoterapisi sonrası MMH gelişen 8 yaşında bir kız vaka bildirilmiştir.

Anahtar Sözcükler: Kanser, Germ hücreli tumor, Moyamoya hastalı̆̆ı, Over tümörü, Vaskülopati

\section{INTRODUCTION}

Moyamoya disease (MMD) is characterized by slowly progressive stenosis of the large vessels of the base of the brain. It is one of the most common cerebrovascular diseases and usually presents with ischemic cerebrovascular episodes in children. The narrowing of the brain arteries seems to be a non-specific reaction of the brain's vessels to a wide variety of stimuli, injuries, or genetic defects. It was firstly described in 1957 as 'hypoplasia of the bilateral internal carotid arteries'. The characteristic appearance of the associated network of abnormally dilated collateral vessels on angiography was later likened to 'something hazy, like a puff of cigarette smoke'; which is named moyamoya in Japanese (1). Patients with the characteristic moyamoya vasculopathy have also wellrecognized associated conditions such as Down syndrome, Neurofibromatosis type-1, and brain tumors are categorized as Moyamoya syndrome, whereas patients with no known associated diseases are said to have Moyamoya disease (26). In children, sella/chiasma region tumors or radiotherapy for intracranial tumors may cause Moyamoya syndrome (MMS) (7). 
An 8-year-old girl who had a history of ovarian endodermal sinus tumor presenting with some neurological abnormalities due to MMD has been presented here. She was diagnosed as MMD by using radiological imaging.

\section{CASE REPORT}

An 8-year-old girl was admitted to the hospital with abdominal pain. Abdominal ultrasonography showed a $15 \times 12 \mathrm{~cm}$ sized solid mass in the pelvic region. Her alpha-fetoprotein (a-FP) level was very high $(35350 \mathrm{lU} / \mathrm{ml})$. After total resection of the mass, she was diagnosed as having endodermal sinus tumor of the right ovary. Chemotherapy consisting of cisplatin, etoposide, and bleomycin was applied for 6 courses. At the end of the treatment, there was no evidence of tumor with normal a-FP level. After 3 months of the treatment, recurrence developed with a splenic lesion and high a-FP level (34 IU/ml). At that time, she was referred to our clinic for further treatment.

On admission to our hospital, her physical examination was normal. Her ultrasonography and abdominal tomography showed a 3x2 cm sized metastatic lesion in the spleen. Her a-FP level increased to $9088 \mathrm{IU} / \mathrm{ml}$. After removal of the tumor with splenectomy, pathological diagnosis was reported as 'splenic metastasis of endodermal sinus tumor'. Salvage chemotherapy consisting of combination of vincristine $1.4 \mathrm{mg} / \mathrm{m}^{2} /$ day on day 1 , cisplatin $90 \mathrm{mg} / \mathrm{m}^{2} /$ day on day 1 , adriamycin $30 \mathrm{mg} / \mathrm{m}^{2}$ on days 1-2, and cyclophosphamide on days 1-3 was administered to the patient every 3 weeks. The a-FP levels gradually decreased to normal range after 2 courses of chemotherapy. After the $2^{\text {nd }}$ cycle of chemotherapy, she suddenly developed motor weakness of her legs. Neurological examination showed that she was unable to walk with the muscle power of 3/5 on left leg. Electromyography (EMG) was planned with the possible diagnosis of peripheral neuropathy. EMG showed no evidence of peripheral neuropathy. Cranial magnetic resonance (MR) imaging showed the presence of abnormal vessel formation in the supracellar, quadrigeminal region, and perimesencephalic cistern and bilateral collateral vessels in the basal ganglia (Figure 1). There was also cerebral infarct in the right parietal cortex. MR angiography showed occlusion of the terminal left internal carotid artery and severe stenosis of the proximal middle and anterior cerebral arteries and prominent moyamoya vasculopathy in the basal ganglia (Figure 2). The radiological findings were interpreted as "Moyamoya disease". Laboratory studies for thrombotic tendency were within normal ranges. Acetyl salicylic acid (ASA) $3 \mathrm{mg} / \mathrm{kg} /$ day was started for the treatment of MMD. Surgical re-vascularization was considered but postponed in our case, because operation was risky during chemotherapy. After 6 courses of chemotherapy, she had no evidence of tumor, whereas had some neurologic signs including as dysarthria, aphasia, and cognitive impairment due to MMD.

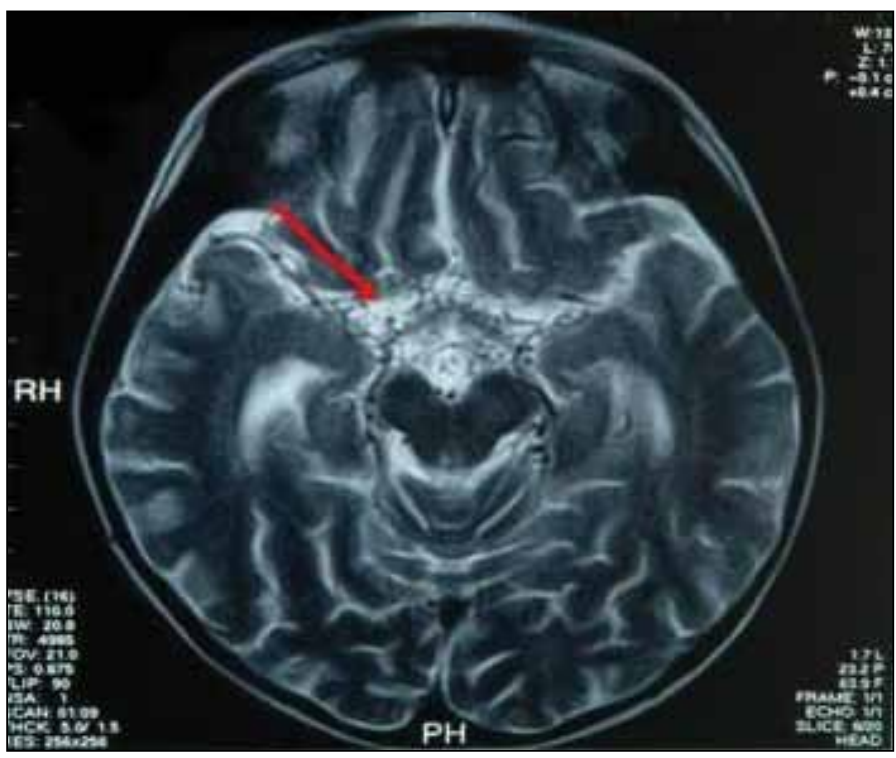

Figure 1: T2-weighted MR image shows multiple collateral vessels as a network.

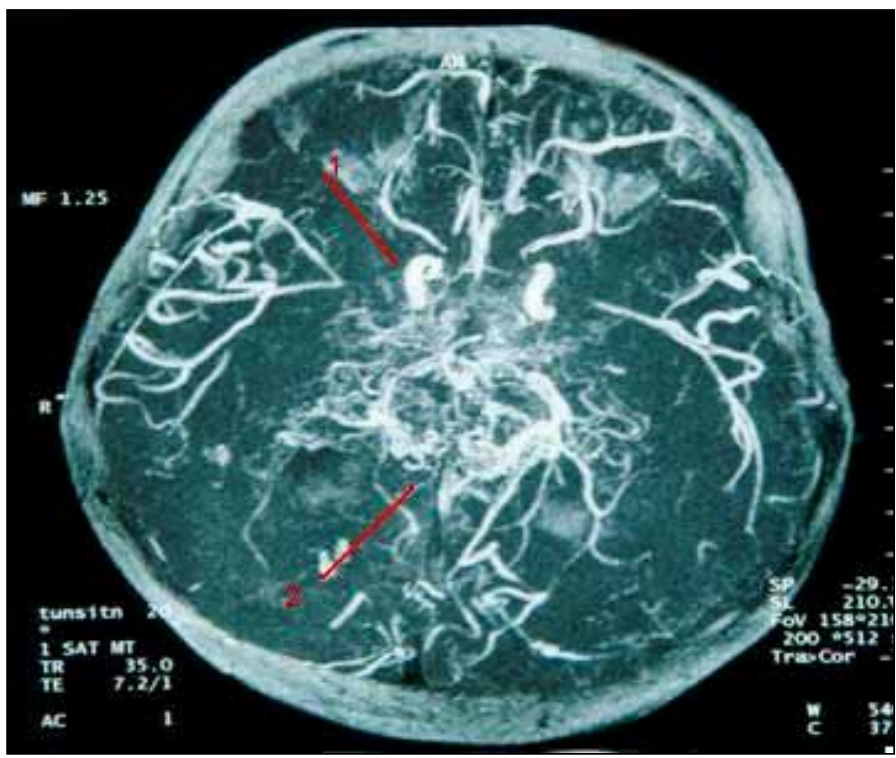

Figure 2: Stenotic portions of the proximal middle cerebral artery and internal carotid artery are indicated by arrows 1. Arterial collaterals called "Moyamoya vessels" are indicated by arrows 2.

\section{DISCUSSION}

Moyamoya disease is characterized by steno-occlusive changes in the circle of Willis, particularly involving the terminal portion of the internal carotid artery, proximal middle cerebral arteries, and anterior cerebral arteries (6). There are 3 types of studies at pathogenesis of MMD: pathologic analysis of affected tissue, genetic studies, and studies of the role of angiogenesis in disease development. It has been suggested that clinical presentation of patients with MMD may be the result of disparate underlying genetic and environmental factors. 
Radiation-induced vasculopathy is one of the late complications of cranial radiotherapy in children with cancer. The use of prophylactic cranial irradiation in patients with leukemia can induce cerebral vasculopathies. It has recently been reported that among 1846 children with leukemia having cranial radiotherapy, 6 children developed MMD (3). This report commented that prophylactic low dose cranial radiotherapy may cause MMD and the children with leukemia should be followed-up closely after cranial radiotherapy. Intracranial tumors or the use of cranial radiotherapy may cause MMD (7-10). In patients with NF-type 1, lower radiotherapy doses are sufficient for the development of MMS (7). Serdaroğlu et al. from our country reported a 4 -year-old girl with NF-type 1 developed MMS (8). The striking feature of that case was the presence of history of radiotherapy for optic glioma. Unlikely, in our case there is neither a presence of NF-type 1 nor a history of cranial radiotherapy. She has no leptomeningeal or intracranial metastasis of tumor. It has been known that some chemotherapeutic agents may have a role in the development of vasculopathy and we cannot definitively exclude a role of chemotherapeutic agents used for germ cell tumor in the development of MMD in our case.

The association of MMD with an extracranial tumor is extremely rare in children. Our case, as far as we know, is the $3^{\text {rd }}$ case with MMD in the background of extracranial solid tumor. Firstly, Watanebe et al (11) reported a case of Wilms tumor associated with MMD in 1985. After than, Buchbinder et al (12) reported a 12-year-old girl who developed MMD after chemotherapy, surgery, and interferon alpha therapy for recurrent osteosarcoma in 2010. They speculated that interferon might affect the balance of endogenous pro-angiogenic and anti-angiogenic factor; which might have played a role in the development of vasculopathy.

Recently, a case of a young boy with NF-type I with glioblastoma who developed MMS after treatment with the angiogenesis inhibitor bevacizumab has been reported by Ullrich et al (13). They supported the hypothesis that inhibition of angiogenic peptides by bevacizumab may contribute in the development of MMD.

Genetic factors play a major role in development of MMD. It has recently been reported that there is a major gene locus on chromosome $17 \mathrm{q} 25$ and a mutation may occur in this region for development of MMD (6).
Both MMD and endodermal sinus tumor might have been caused by same underlying genetic abnormality. Unfortunately, a detailed genetic study could not be performed in our patient. In the English literature, a coincidental case of an ovarian tumor and MMD has not been reported yet. In fact, it is difficult to conclude that these two events are linked. MMD may be idiopathic and our case may be a coincidental event.

\section{REFERENCES}

1. Takeuchi K, Shimizu K. Hypoplasia of the bilateral internal carotid arteries. Brain Nerve 1957;9:37-43.

2. Horn P, Pfister S, Bueltman E, Vajkoczy P, Schmiedek P. Moyamoyalike vasculopathy (moyamoya syndrome) in children. Childs Nerv Syst 2004;20:382-91.

3. Kikuchi A, Maeda M, Hanada R, Okimoto Y, Ishimoto K, Kaneko T, et al. Moyamoya syndrome following childhood acute lymphoblastic leukemia. Pediatr Blood Cancer 2007;48:268-72.

4. Kitano S, Sakamoto H, Fujitani K, Kobayashi Y. Moyamoya disease associated with a brain stem glioma. Childs Nerv Syst 2000;16:251-5.

5. Rosser TL, Vezina G, Packer RJ. Cerebrovascular abnormalities in a population of children with neurofibromatosis type 1. Neurology 2005;64:553-5.

6. Scott RM, Smith ER. Moyamoya disease and moyamoya syndrome. N Eng J Med 2009;360:1226-37.

7. Desai SS, Paulino AC, Mai WY, Teh BS. Radiation-induced moyamoya syndrome. Int J Radiat Oncol Biol Phys 2006;65: 1222-7.

8. Serdaroğlu A, Şimşek F, Gücüyener K, Oğuz A, Karadeniz C, Balibey M. Moyamoya syndrome after radiation therapy for optic pathway glioma: Case report. J Child Neurol 2000;15:765-7.

9. Kondoh T, Morishita A, Kamei M, Okamura Y, Tamaki M, Kohmura E. Moyamoya syndrome after prophylactic cranial irradiation for acute lymphocytic leukemia. Pediatr Neurosurg 2003;39:264-9.

10. Ullrich NJ, Robertson R, Kinnamon DD, Scott RM, Kieran MW, Turner CD, et al. Moyamoya following cranial irradiation for primary brain tumors in children. Neurology 2007;68:932-8.

11. Watanabe Y, Todani T, Fujii T, Toki A, Uemura S, Koike Y. Wilm's tumor associated with Moyamoya disease: A case report. Z Kinderchir 1985; 40:114-6.

12. Buchbinder D, Steinberg G, Linetsky M, Casillas J. Moyamoya in a child treated with interferon for recurrent osteosarcoma. J Pediatr Hematol Oncol 2010;32:476-8.

13. Ullrich NJ, Zimmerman MA, Smith E, Irons M, Marcus K, Kieran MW. Association of rapidly progressive moyamoya syndrome with Bevacizumab treatment for Glioblastoma in a child with neurofibromatosis type I. J Child Neurol 2011;26:228-30. 